\title{
14
}

\section{Becoming a Decision-Maker, or: "Don't Turn Your Heart into a Den of Thieves and Murderers"}

\author{
Stephanie Schneider
}

\section{Introduction}

As a particular kind of authorial work practice, asylum casework revolves around the central goal of producing sovereign decisions. But how are people taught to decide asylum cases on a routine basis? How are they expected to deal with the uncertainties, ambiguities, and the moral and ethical quandaries involved in carrying out this task? Based on observations of an introductory training course for decision-makers, the present paper will show how the induction of caseworkers in Germany centrally revolves around (a) the proper type and degree of emotional involvement and (b) the proper type and degree of individual autonomy and creativity in handling the 'stuff' of casework. It is argued that casework may usefully be understood as an ongoing process of boundary work (Gieryn 1983) in which the written decision functions as a boundary object (Star and Griesemer 1989; Star 2010) circulating among different groups of actors. During the training, references to emotions and materialities became linked in specific ways, depending on the phase of the procedure and the potential addressee. The analysis shows how seemingly mundane and routine aspects of asylum casework are deeply conflictual and emotionally charged.

\footnotetext{
S. Schneider $(\square)$

Department of Social Sciences, University of Siegen, Siegen, Germany e-mail: schneider@soziologie.uni-siegen.de
} 
Asylum decisions are acts of certification that produce categories of identity, status and belonging. Bureaucratic work rests on systems of classification and categorisation (Bowker and Star 1999), it continuously imposes, (re)produces and is itself bound by 'principles of vision and division' (Bourdieu 1994: 12-18) that present themselves as universal, disinterested and oriented towards the 'common good'. What constitutes a 'good' decision, however, was and is an object of constant struggles. To mention but a few: administrative asylum decision-making is characterised by goal conflicts such as 'offering protection' vs. 'preventing abuse of the asylum system'. In processing cases, staff members are expected to not only act legitimately but also efficiently - a point that is of particular importance in asylum systems with high caseloads. Furthermore, and this will be at the centre of the following discussion, a decision must both be as transparent as necessary and remain as opaque as possible. A minimum of transparency is required both for organisational steering efforts and for ensuring legal certainty. At the same time, not all considerations that impact on the decision-makingprocess (e.g., organisational quotas concerning the duration of asylum interviews, caseworkers' feelings and emotions) find their way into the endproduct of casework. In the written decision, the work that is invested into juggling these potentially conflicting demands is naturalised, objectified, and hence rendered invisible (Bourdieu 1989: 21ff.).

A number of studies have investigated asylum authorities 'from within' and pointed to the significance of individual and collective routines in dealing with the uncertainties, ambiguities and dilemmas of asylum procedures (Affolter 2017; Dahlvik 2014a; Probst 2012; Scheffer 2001; Schittenhelm 2015; Wettergren and Wikström 2014). They have stressed the extent to which a "culture of disbelief" impacts on decision-making-practices within the authorities and shown that the categorisations that caseworkers use in their daily work are to a great extent determined by organisational subcultures rather than by law or politics (Jubany 2011; Good 2015; Whyte 2015; Wikström and Johansson 2013). The present chapter builds on and seeks to contribute to this body of research by asking how newly recruited staff are initiated into practices of interviewing and decision-making. For newcomers, the above-mentioned ambivalences are exacerbated by their lack of knowledge about organisational routines, expectations and rules. While I do not by any means suppose that training courses are in any simple way causally linked to actual refugee status determination practices, they are enlightening insofar as they constitute situations in which the takenfor-grantedness of organisational routines becomes an object of explication. During the training, particular aspects of casework were problematised, 
rendered explicit and in this sense made public (Schmidt and Volbers 2011) to both the participants of the training and the outside observer. By focusing on how relations to different actors, objects, and emotions are rendered relevant during the training, the asylum administration becomes analysable as part of an only ever relatively autonomous field (Moore 1972; Bourdieu 1998; Bourdieu and Wacquant 2013; see Gill and Good, this volume) and the processual and conflictual character of asylum casework come into view.

The chapter is structured as follows: after a section on fieldwork and methods, I provide a brief overview of the administrative setting at the time of fieldwork in 2013/2014 and point to major changes since then. Subsequently, I focus on the ways in which beginning caseworkers are inducted into asylum procedural practices and interviewing and decisionmaking in particular. In the concluding section, I return to the role of emotions and materialities in boundary work in the asylum administrative setting.

\section{Fieldwork and Methods}

Fieldwork was conducted within the German Federal Office for Migration and Refugees (Bundesamt für Migration und Flüchtlinge, BAMF) in 2013 and $2014 .{ }^{1}$ As a participant observer, I took part in three different training courses for decision-makers. Semi-structured interviews were conducted with trainers, caseworkers and headquarter staff involved in training and quality measures. As a non-participant observer, I visited different branch offices for short periods of one to five days. In the course of fieldwork, a variety of documents pertaining to asylum casework (training material, handbooks, guidelines, country of origin information: etc.) was collected.

For data analysis, I use a multi-method design that combines mapping techniques developed for situational analysis (Clarke 2012) with the documentary method (Bohnsack 2010; Nohl 2012), a procedure based on a sociology of knowledge approach. These are employed to develop different and partial perspectives on the material (Mannheim 2013 [1936]: 237280). Situational maps were used to 'lay out the major human, nonhuman,

\footnotetext{
${ }^{1}$ The data were collected in the context of a research project on transnational administrative cooperation between European asylum authorities entitled 'Europeanization of Asylum Administrative Practice?' (headed by Christian Lahusen and Karin Schittenhelm at the University of Siegen), and funded by the German Research Foundation (DFG) as part of the research group 'Horizontal Europeanization' (FOR1539).
} 
discursive, and other elements in the research situation of concern and provoke analyses of relations among them' (Clarke 2003: 559). The reconstructive interpretations of select passages from interviews and field notes were geared towards a more detailed analysis of the frames of reference and patterns of perception, interpretation and evaluation of research participants by focusing on how they narrate, describe, argue and evaluate either during the interview or in the situations observed. For the purposes of this paper, I concentrate on field notes taken during a five-day introductory training course for asylum caseworkers. Since interviewing and decision-making form the core tasks of caseworkers, the two units that were devoted to these aspects were singled out for the following analysis. For presentation purposes, the original German vignettes were slightly shortened and translated into English by the author.

Before going into the training, the next section will offer a brief overview of asylum procedural practices in Germany at the time of fieldwork. Where applicable, I indicate and describe more recent changes.

\section{The Asylum-Administrative Setting in Germany}

The German Federal Office for Migration and Refugees (Bundesamt für Migration and Flüchtlinge: BAMF) is the central operative authority responsible for deciding upon asylum applications. It is subordinate to the Ministry of the Interior and exercises its functions via decentralised branch-offices across the country. While people seeking international protection may be registered by several state institutions, to initiate the formal asylum procedure and to become an applicant in the legal sense, the protection seeker must apply for asylum in person at a branch office of BAMF. ${ }^{2}$ Unlike in some other European countries (e.g., Sweden, see Schneider and Wottrich 2017), BAMF is solely responsible for taking decisions on asylum requests whereas all issues related to residence, social security, health, work, and housing are dealt with by the local foreigners' authorities under the jurisdiction of the federal states. That is, caseworkers of the federal office will usually have very little information on the living conditions of the people whose cases they process. In addition, even the direct consequences of their decisions, i.e., either the granting of a residence permit or a deportation

${ }^{2}$ In exceptional cases, an application may be lodged in writing. In 2015, this was the case for a considerable number of applications from Syria, Iraq, and Eritrea (Deutscher Bundestag 2015). 
order, will be administered and carried through by local authorities and/or the police.

After an all-time low of 19,164 initial applications in 2007, there has been a rapid increase in entry figures with 109,580 initial applications in 2013 and 441,899 in 2015 (Bundesamt für Migration und Flüchtlinge 2016: 13). Furthermore, the overall backlog of undecided cases has grown substantially, from 10,926 in 2007 and 95,743 in 2013 to 364,664 in 2015 (Bundesamt für Migration und Flüchtlinge 2016: 56; Thränhardt 2014). ${ }^{3}$ Due to the very restricted recruitment of new asylum caseworkers from 1993 onwards (Kreienbrink 2013: 406) and with the massive recruitment wave of 2015 and 2016, there is now a considerable age gap between staff that have twenty and more years of professional experience within BAMF and newly hired staff (Schittenhelm and Schneider 2017). As of 1st January 2014, roughly 289 caseworkers were responsible for investigating and deciding on asylum and/or Dublin cases, i.e., cases in which the responsibility of a member state for processing an asylum claim has yet to be determined (Deutscher Bundestag 2014: 38). By 1st September 2016 this number had risen to 1687 (Deutscher Bundestag 2016: 7, 11), although a substantial portion only had time-limited employment contracts. Until recently, caseworkers were mainly recruited from institutions qualifying for entry into public administrative service (such as the Federal University of Applied Administrative Science) or from other federal authorities (e.g., the federal police, the armed forces, the federal pension fund or the customs authorities). Since 2015, entry requirements have been loosened so that anybody with a bachelor's degree may apply. The specific kind of knowledge relevant for asylum casework is largely acquired on the job and during internal training measures. The length and nature of the induction phase have changed considerably over the last couple of years. At the time of fieldwork, new staff members were usually trained on-the-job for a period of roughly three months (sometimes less) under the supervision of more experienced colleagues or mentors. In addition, they received training courses at the headquarters in Nuremberg that covered legal aspects, intercultural training, Country of Origin Information (COI), and more practical aspects of casework. Starting in 2015, qualification centres have been set up where newcomers undergo somewhat more systematic but very short initial training courses of four to eight weeks, depending on anticipated tasks.

\footnotetext{
${ }^{3}$ This backlog and the significant delays in stepping up the office's staff and resources when applications started to increase from 2012 onwards were a recurrent theme in conversations during fieldwork.
} 
At the time of fieldwork, there was no explicit differentiation between the functions of conducting the substantive interview on the one hand and delivering decisions on the other. To the contrary, the unity of investigating and decision-making functions was something that the organisation aspired to in order to ensure adequate credibility judgements and to prevent a mass-processing of cases on the basis of the file alone. In practice, however, a considerable number of cases were decided by people who had not conducted the interview, especially in branch-offices with extreme case overload or in situations where certain countries of origin were prioritised. With the introduction of so-called arrival- and decision-centres in 2015, the separation of tasks into interviewing and decision-making has become even more common.

With the passing of the immigration act in 2005, BAMF was assigned greater responsibility for issues of quality assessment and assurance. ${ }^{4}$ Since then, caseworkers are subject to the directives of their superiors (and, ultimately, the Ministry of the Interior) whereas before they were to decide independently and on the basis of the law only. ${ }^{5}$ Unity of decision-makingpractices is supposed to be guaranteed by internal guidelines and directives for particular case-constellations or countries of origin, including templates for writing decisions. That is, over the last couple of decades, the categorisations relevant for decision-making have become more explicit and more binding - in a sense, more bureaucratic. The reforms of 2015/2016 towards 'integrated refugee management' have further strengthened these tendencies since cases are now clustered into four main categories (countries of origin with a protection rate above $50 \%$, countries of origin with a protection rate below 20\%, 'complex profiles', Dublin-cases) before they even reach case-officers' desks. Unlike in many other European asylum authorities where decisions are evaluated and signed by senior officials, caseworkers sign the written decision with their own name on behalf of BAMF. Via forms containing a brief overview of the decision, these are cross-checked by superiors in local branch offices. Appeals against negative decisions have to be lodged at the administrative courts within seven or fourteen calendar

\footnotetext{
${ }^{4}$ Before, this had been the task of the Federal Commissioner for Asylum Matters who was responsible for safeguarding the public interest and establishing uniform decision-making-practices within the asylum authority and before the courts (Kreienbrink 2013: 400). In the vast majority of cases, he appealed positive decisions (Weber 1998: 65; Unabhängige Kommission 'Zuwanderung' 2001: 144).

${ }^{5}$ The former practice was aimed at insulating asylum decision-making from political interference (Unabhängige Kommission 'Zuwanderung' 2001: 143). However, caseworkers seemed to apply legal provisions in an overly restrictive manner, which eventually came into conflict with political expectations (especially in the context of European efforts at harmonisation).
} 
days depending on the type of rejection. Appeals against simple rejections have suspensive effect whereas those against claims rejected as manifestly unfounded or inadmissible do not. Applications to restore substantive effect must be substantiated and forwarded to the courts within seven calendar days. Decisions of the administrative courts are usually final: only in exceptional cases is it possible to appeal to higher instances (the High and the Federal Administrative Courts) or to lodge a constitutional complaint at the Federal Constitutional Court.

\section{Organised Detachment}

Interviews and observations at branch-offices showed how the organisation of casework on the ground further contributed to spatial, temporal, and emotional distance between caseworkers and asylum applicants. At local branch offices, staffs of the middle administrative service were responsible for registering the asylum request. They had their offices on the ground floor of the administrative buildings, which was also where the reception areas and waiting rooms for asylum applicants were located. With the help of an interpreter, staff informed applicants about the procedure, conducted a short initial interview on identity, travel routes and family relations, and opened up the electronic file. In the 'ED-Room', applicants were fingerprinted, photographed, and their height measured. These procedures inevitably involved some form of bodily contact, especially when bodies did not conform to the requirements of the technical devices used, as is often the case with fingerprinting. ${ }^{6}$ It was also here that the scanners, printers and photocopying machines that served to produce and reproduce all the data that would eventually find their way into the electronic file were to be found. In short, this was where the 'dirty work' was done. This area was usually separated from the other areas of the building by security doors which-unless you were in possession of a key card-could only be opened from the inside. At the end of this initial screening, applicants were handed their residence permit (Aufenthaltsgestattung) for the duration of the procedure and told they would be informed about their appointment for the substantive interview at a later stage.

The offices of the members of the higher administrative service who are the subject of this paper, i.e., the people who conduct interviews and make

\footnotetext{
${ }^{6}$ Apart from deliberate manipulation, fingers might be too old, too leathern from work, etc.
} 
decisions, were located in the upper storeys of the building. Generally, it was much quieter and cleaner here and the pace of work seemed slower, at least to the outside observer. Applicants could only enter this area once they had been collected from the waiting-rooms downstairs and brought to their interviewing officer. All applicants were invited for eight o'clock in the morning, meaning that many had to wait long hours, often with no access to food and beverages since branch offices were often located in far out and inhospitable areas. Asylum case officers usually only met their 'clients' on this one occasion. The interviews took place in caseworkers' offices whichapart from smaller individual details - were quite similarly furnished with officers seated behind large desks fitted with computers, and applicant and interpreter at a smaller desk in front on which water, tissues, a few sheets of white paper and pens were placed. In most cases, I took my seat at the side or in a corner near the door, facing the caseworker. At none of the interviews I observed was a legal counsel present and caseworkers told me that in their daily work this was nothing unusual. ${ }^{7}$ Routinely, the interview situation was thus restricted to an interaction between caseworker, interpreter, and applicant. While interviewees often emphasised that this setting helped to generate an atmosphere of trust, it also contributed to the opacity of the substantive interview (Schneider and Wottrich 2017).

While the interviews seemed highly ritualised regarding both their opening $^{8}$ and ending9 sequences, differences in interviewing style became apparent with regard to the heart of the substantive interview. Here, applicants are asked to freely narrate their reasons for seeking protection and caseworkers are supposed to further enquire into the facts of the case and to give applicants the chance to clarify possible discrepancies or contradictions. Regarding the observed differences in interviewing techniques, our research has shown that there is a strong belief among German caseworkers that this is and should remain a matter of personality and individual style (Schneider and Wottrich 2017). Next to the ways in which questions are asked, the transformation of the spoken and translated word into the written protocol is a complex process with its own challenges and pitfalls (Dahlvik 2014b;

\footnotetext{
${ }^{7}$ Unlike in some other European countries, e.g., Sweden, free legal counsel is not provided for during first-instance procedures in Germany (Schneider and Wottrich 2017).

${ }^{8}$ For example, all caseworkers enquired about applicants' well-being, ensured them of confidentiality, explained the purpose of the interview and then asked a set of questions from a standardised questionnaire.

${ }^{9}$ These often contained formulaic questions required by law like 'What do you fear upon return to your home country?' and 'Were you able to communicate with the interpreter?' etc.
} 
Scheffer 1998; see also the contributions in Part II of this volume). This is of particular relevance in the German case since interviews are not recorded. Again, caseworkers' routines were rather heterogeneous in this regard, with some working with a dictaphone only, others typing or taking handwritten notes, and yet others using voice recognition software. At the end of the substantive interview, applicants were asked whether they wished to have the protocol translated back to them. In most cases I observed they declined and left. ${ }^{10}$ Presumably, this would have been different had they been accompanied by a legal representative.

After the interview, caseworkers need to use powers of practical judgement in order to assess and decide each case on an individual basis. In their decisions, they are asked to observe and apply legally binding rules and norms which, however, can in themselves be contradictory and in need of explication. A large share of the organisation's steering effort goes into the development of tools and aids that are meant to ensure a uniform application of the office's policy. At the same time, output-oriented practices of controlling and steering played an important role in life at the office during the time of fieldwork. Instruments such as 'MARiS', the agency's documentand workflow-management-system, and 'OrAs', an internal quota-system that specified productivity norms, introduced a logic of calculability and countability into the asylum decision-making process: via automatons, the completion of particular steps of the procedure was counted and entered the Board's statistics, which, on the one hand, were one of the most important means by which the organisation's performance was measured in terms of legitimacy and efficiency, and, on the other hand, also one of the prime instruments of control that the organisation exercised over its staff. The number of asylum interviews conducted and decisions written was important in the assessment of caseworkers' performance and could be consequential regarding promotions or their eventual appointment as tenured civil servants. What was counted and what was not affected the ways in which caseworkers perceived asylum applicants and their own work. Some interviewees talked about applicants only as workloads to be processed, and cases were described as difficult or easy depending on the anticipated time it was going to take to close the file (Schittenhelm 2015; Schittenhelm and Schneider 2017). Depending on organisational prioritisation and individual coping strategies, some cases were treated more quickly than others. Since

\footnotetext{
${ }^{10}$ Some caseworkers did, however, have the interpreter translate the protocol back block by block during the actual interview.
} 
'MARiS' supports a kind of file-management that can render some cases very clearly visible and others nearly invisible (through various types of hold-files), it simultaneously enabled an emotional detachment from such differential treatment and from the fact that there were always more cases than one could possibly process. Taken together, the ways in which asylum casework was structured contributed to an administrative setting which was characterised by spatial, temporal and emotional distance between caseworkers and clients (for similar tendencies in the UK-context, see Gill 2016). As I will show below, the training was geared at counteracting the potential dangers resulting from this setting.

\section{“Don't Turn Your Heart into a Den of Thieves and Murderers"}

The vignettes presented in the following stem from field-notes taken during a five-day basic introductory course for asylum caseworkers. Of the ten participants, six were recently recruited staff with one to five months work experience whereas four had been ordered to re-enter the asylum unit in the context of rising application numbers after they had worked in other parts of the organisation for a number of years. Regarding gender, the group was split evenly. The units that are of particular interest here-interviewing and drafting-and-decision-making - were delivered jointly by headquarter staff responsible for quality assurance and experienced caseworkers from branch offices. Both units began with an input in the form of a lecture and then proceeded with a workshop unit during which trainees participated more actively and more practical issues were discussed.

\section{Learning How to Interview}

The first part of the session on interviewing techniques consisted of a lecture delivered jointly by BAMF staff and a representative from UNHCR. The overarching goal of asylum interviews was formulated as clarifying all questions relevant for decision-making in a fair and efficient manner. Particular ways of conducting interviews were discredited and trainers called on caseworkers to be empathetic, fair, loyal, sensitive, and open. To create a respectful interview atmosphere, they were advised to greet applicants in their own 
language, to enquire about their well-being, to offer water, to have tissues at their disposal etc. Ultimately, these recommendations aimed at transforming interviewing practices from 'police style' to 'dialogic communication' (Schneider and Wottrich 2017). They also indicated the desired emotional stance that caseworkers should take towards applicants, namely one of friendly neutrality. After the UNHCR representative had left, the workshop unit on interviewing techniques began. It started out with an input on credibility assessment by one of the trainers:

\begin{abstract}
A handout containing a list of 'reality criteria' ${ }^{11}$ based on forensic psychology is distributed. Trainer B emphasises that this is a summary of the state of the art at the end of the 1990s when the office had commissioned a very expensive workshop by a highly acclaimed forensic psychologist for all decision-makers. He says he doesn't know whether much has changed in this regard since then. However, he says, the office now knows that a lack of reality criteria is not necessarily indicative of a lie. [...] Trainer says it is a difficult topic. However, 'I still work like [professor X] told us'. He says he knows this is far from perfect but that he couldn't offer anything else at the moment. The office was going to update the material and introduce new methods for credibility assessment that he was curious to see but this was going to take another while. [...] After having presented the different criteria in detail, the trainer recommends using the handout like a "blueprint" to lay over the written protocol of the asylum interview. He mentions non-verbal information gathered during the face-to-face-interaction and growing experience as a caseworker as additional helpful ingredients in determining credibility. His colleague quickly adds that non-verbal information and impressions should be noted in the written protocol so that third parties could relate to it, too.
\end{abstract}

The fact that the workshop unit on interviewing began with credibility assessment already shows how closely linked interviewing and decisionmaking are. While the input lecture centrally revolved around applicants' right to be heard and around caseworkers' duties regarding transparency and proper treatment of applicants what caseworkers apparently really need to learn is how to tell a truth from a lie. This is fundamental in maintaining the illusio that the asylum-bureaucratic game is worth playing. If everything were to be taken at face-value, there would be no need for a decision, no need for caseworkers, no need for an asylum authority at all. The vignette

\footnotetext{
${ }^{11}$ For example, logical consistency of statements, and unstructured and detailed narrations that include descriptions of interactions, one's own emotions, complications in the course of action etc.
} 
above illustrates how concepts from the world of academia may be imported and used to endow administrative practices with an aura of authority, however outdated they might be. In the form of check-lists, they are turned into useful tools for handling the complexities of credibility assessments (for comparison, see Sorgoni, this volume).

After this opening, trainers asked participants to jot down any questions they might have concerning the asylum interview. Interestingly, the ensuing discussion quickly moved away from the question of credibility and truth and focused instead on issues of personal security, health and well-being. Caseworkers were concerned, e.g., about how to react when an applicant was infected with dysentery, critiqued the lack of security measures within the office, and one person made a sarcastic comment on how his main concern was that the bucket (to puke into) wasn't at hand in time. This initial discussion showed how caseworkers used the training above all as a space to voice concerns and to exchange personal experiences of their daily work with colleagues in a safe and closed environment. The frequent reference to the body, to issues associated with fear and/or disgust, were indicative of the emotional aspects of their daily work. ${ }^{12}$ Trainers related to these concerns in an empathetic way but also emphasised that asylum interviews were no more dangerous than riding the tram and that all applicants underwent a prior health-check. Concerning security, they argued that the situation at BAMF was different from that at local foreigners' authorities (who are responsible for enforcing deportations) since caseworkers first of all had something to offer to applicants. ${ }^{13}$ Differences in power and status, the division of labour and the various forms of organisational distancing described above were thus used to alleviate feelings of insecurity, threat and disgust.

Later on, the group returned to discuss questions of credibility assessment. Questions revolved around how to deal with doubts concerning the truthfulness of statements during the interview in general and around credibility assessments concerning religious conversion and sexual orientation in particular:

One of the older participants asks how one could possibly get to the bottom of such things. He would consider this to be very very difficult considering that applicants could prepare in advance. Trainer A answers that such things should

\footnotetext{
${ }^{12}$ On the role of disgust in organisations, see Klatetzki (2016).

${ }^{13}$ Trainers contrasted this with the situation in Sweden where caseworkers had to personally communicate negative decisions to applicants.
} 
always be considered in light of the country-specific guidelines. Questioner replies that these would not help him to know whether the applicant had really converted to Christianity. This was very difficult for him because these were things taking place inside the applicant.

Questions like these illustrate how caseworkers were thankful for expertise, tools and 'tricks of the trade' to help them cope with uncertainties. However, eventual hopes of receiving clear guidance were frequently frustrated:

Trainer B goes on to say that, regarding homosexuality, sometimes there are very moving stories that need to be transported, too. 'There, I want to feel the vibrations' $[\ldots]$. After a discussion about the situation in a particular country of origin, the questioner again insists: There I have guidelines on how to decide. But my question was whether I believe him or not. Trainer A reacts, 'well, that's your job', 'that's why this is so highly qualified', 'that's something you have to bite yourself through', 'there are no hard and fast rules'. A participant sitting close to me whispers, 'Very helpful indeed'.

Against the backdrop of a huge apparatus of written rules, guidelines and databases, caseworkers were thus thrown back on their 'emotional intelligence' as human beings (see also Kobelinsky and Liodden, both this volume). Importantly, this concerned not only the type of emotional display that was required of caseworkers during the interaction with applicants which might be considered a form of emotional labour (Hochschild 2003). It also involved using their bodies' sensorimotor systems to decipher applicants' emotional displays, that is, as a kind of lie-detector. And furthermore, when all else failed, trainers appealed to caseworkers' pride and implicitly urged them to develop a habitus comparable to a judge ${ }^{14}$ - a conception that is deeply entrenched in the organisational history of BAMF, where for a long time caseworkers used to act independently from directives, bound only by law and their 'intimate conviction' (see also Kobelinsky, this volume). The latter is a notion of central relevance in the German legal tradition and requires that decision-makers be inwardly convinced about the certainty and truthfulness of the information before them (on the difference between inquisitorial and adversarial asylum procedures, see Staffans 2008). Caseworkers were asked to enter into a kind of self-dialogue, to constantly monitor their own emotions and use them as guidance in situations of uncertainty. During the subsequent discussion of a protocol of an exemplary

\footnotetext{
${ }^{14}$ During the other training courses I observed, similar statements included "that's what you're here for, you just have to decide", "you are the decision-maker".
} 
substantive interview, participants were asked to use the list of reality criteria to assess the credibility of the statements. Although the majority, including trainers, agreed that the overall story was coherent and plausible, two of the participants remained unconvinced:

Trainer B recommends paying attention to the reality criteria in the course of the interview and states that apparently participants used different standards. He suggests taking the time to go over the protocol in an unburdened way, maybe using a highlighter, and to then see what outweighs. He says, 'at the end of the day, I can't write a rejection if I think he told me the truth', 'don't turn your heart into a den of thieves and murderers', 'don't act against your own conviction'.

Appeals like these may be considered as efforts to insert or reintroduce the sentient bureaucrat-conceived as a 'good' person-as a means to combat practices that are seen as being too entrenched in (individual or branchspecific) routines and as having, in a sense, become irrational. ${ }^{15}$ The quote above gives us an idea of the direction this irrationality might take, namely that applications are rejected in spite of caseworkers' conviction of the truthfulness of the account. While remaining implicit, this points to the possibility that frontline-practices might become dominated by the 'wrong' emotions, either in the sense of moral indifference or even 'negative' emotions towards applicants. The list and the highlighter are turned into tools compensating for such an alleged lack of emotional reflexivity (Burkitt 2012).

\section{Learning How to Write Decisions}

The workshop unit on drafting decisions centrally revolved around the ways in which caseworkers should handle the written guidelines and templates for decision-making. During the training, trainers stressed how these functioned to safeguard transparency, efficiency, uniformity and lawfulness of decision-making practices. They also emphasised, however, that the flipside consists in the danger of not treating cases individually. A lot of effort was put into exposing and counteracting the dysfunctionalities of an excessive use of templates. The operative part of the decision was portrayed as the

\footnotetext{
${ }^{15}$ That is, they constitute efforts to maintain the status of asylum decision-making as a moral enterprise (Fassin and Kobelinsky 2012).
} 
"core of the administrative act" and the statement of the facts of the case deemed a "high art". The written decision was likened to BAMF's "business card" and instructors urged caseworkers to keep in mind that they sign it with their own name and personally stand for it, that it was thus also their own personal business card. The metaphorical language used by the trainer vividly refers to the relations between the world of the administration and the 'outside world'. The decision is that which leaves the organisation, which is handed over to external actors and which may be used as an indicator of the office's performance. At the same time, it connects the work of caseworkers to that of other actors within the organisation and may also be used as an indicator of their own individual performance. As such, it is closely linked to the emotions of pride and shame. What constitutes a 'good decision' was then further specified by the trainer:

The pre-formulated paragraphs for decisions are beneficial for not having to start from scratch each time anew. They are a blessing, in the sense of making life easier and to make you feel secure, but also a curse since they may seduce one into using them alone. It is important, however, that you get the transitions right and that you include very personal, individual things.

To write a decision 'properly' is thus a skilful and creative undertaking. However, the creativity demanded of caseworkers is restricted to particular elements of the decision and depends on the addressee. The operative part of the decision is always well structured, in the sense of it being based on standardised, pre-formulated paragraphs which are available in a variety of languages. This part of the decision is something that caseworkers are not supposed to change. Its main addressee is the applicant. The elaboration of the grounds for (negative) decisions, in contrast, is above all addressed at potential judicial review and not translated into the applicant's language. The relations between courts and administration are structured according to the necessity of making the work going into the administrative decision accountable. From the trainers' perspective, this requires an active transformation of the tools and aids provided by the organisation. It is caseworkers' responsibility to argue each individual decision and to use the available templates only if and where they fit the individual case. In this sense, the elaboration of the grounds of the decision is - or rather should be-an ill structured element of the decision (on the back-and-forth between ill and well structured, see Star 2010). When aids and tools are used without taking account of the individuality of each claim, the decision can lose its status. It 
becomes a defective decision that as such may be rendered useless or even prove detrimental to the organisation's reputation.

If, why, and how decisions should be argued was a subject of recurrent discussion during this training session. The relative autonomy of the organisation would be challenged if all the elements that enter into the decision-making process were to be made transparent. In particular, this concerns grounds for positive decisions. These go into an internal note but do not enter the written decision handed over to applicants. During the training, caseworkers' reasoning revolved around the danger of providing future applicants with a blueprint for their statements during the substantive interview if the office's policy regarding specific countries of origin or specific case constellations were to be made public. In this regard, writing decisions is always a work of immunisation, too.

What becomes obvious, then, is that next to its interpretative flexibility (a decision means something different to a caseworker, a quality supervisor, a head of a branch unit, a lawyer, an asylum applicant) the written decision constitutes a shared space between the asylum administrative authority and the wider social world and enables a kind of cooperation without consensus between a variety of different actors (Star 2010: 602). A lot of this cooperation rests on the invisible work done in caseworkers' offices (Star and Strauss 1999). While the organisational setting in which this work is done induces more standardisation, trainers are at pains to emphasise that particular elements of the decision need to be ill structured. The dilemma that characterises the decision-making process from the perspective of caseworkers can thus be formulated as a situation in which they are subject to major, even excessive, regulation through the organisation and the Ministry of the Interior, on the one hand, but are held personally accountable for the quality of decisions, on the other.

\section{Conclusions and Outlook}

Bureaucracy, in the Weberian ideal-typical characterisation, is geared to the efficient and effective implementation of rules. These rules should be applied in a rational, objective, fair, and impersonal manner. As a source of legitimacy, this model has come under increasing attack. In the literature, the general shift to procedural justice and proximity to citizens as new sources of legitimacy has been associated with more personal, even empathetic styles of executing bureaucratic tasks (Englert and Sondermann 2013). Within the German asylum administration, this shift takes on a particular twist. In the 
course of the training, the bifurcation of rational application of rules and more intuitive, emotionally based approaches to casework were both challenged and reinforced. An analysis of the processual character of casework is helpful in explaining this apparent paradox.

While the emotions that inform the process of decision-making do not appear on the surface of the written end-product, they are central at several moments of the procedure. As the vignettes illustrate, the face-to-face interaction between caseworkers and applicants may be infused with emotions like pity, fear, and disgust. Here, caseworkers are expected to engage in emotional labour by developing a neutral, yet empathetic stance towards applicants. Given working conditions on the ground, this is something that must be actively and consciously cultivated. Artefacts like the glass of water on the table may function as potential symbolic substitutes for such emotion work. In the discussions surrounding credibility assessments, in contrast, emotional appraisals were presented as being useful both as 'lie-detectors' and as 'moral compasses'. They are important in linking the situation of interviewing with writing the decision. Here, emotions are not so much something to be suppressed, controlled or managed but rather form part of more implicit ways of knowing-how, of intuiting situations and deciding which course of action to take. Trainers' rather awkward reactions to participants' questions illustrate the difficulties they are having in explicating this type of knowledge. Where they get the impression that emotional appraisals point participants into the 'wrong' direction, they refer caseworkers to tools like the list and the highlighter.

Finally, the workshop unit on writing decisions was infused with references to pride and shame, arguably the social emotion per se (Scheff 2000). In this context, remnants of the former autonomy of caseworkers formed an important point of reference for trainers' appeals to caseworkers' sense of responsibility. Symbolically, this found expression in the fact that it was still individual decision-makers who signed the decision with their own name. The subjectification of responsibility was legitimated and further reinforced by the organisational narrative of the decision-maker as a quasi-judge-i.e., a professional who is expected to act according to the letter of the law and according to her own work-ethos-but without the merits that used to go along with that: the power and autonomy to defend decisions departing from political or organisational expectations with reference to one's 'intimate conviction'. Given working conditions on the ground, appeals to caseworkers' pride and their capacities for empathy and emotional reflexivity are potentially offset by the fact that it is output rather than quality that is positively sanctioned. In this context, the various artefacts meant to decrease the 
complexities of work (the list, the guideline, the template) might not reduce but rather displace them (Star and Strauss 1999: 25) — to the detriment of both caseworkers and applicants.

Since casework revolves around the written decision as the one central object linking the world of the administration with the wider social world, the various ways in which emotions and materialities are linked during the different steps in the production of this object are deeply political. Amongst others, they influence which elements of the decision-making process are made transparent or rendered opaque and thus have consequences for the ways in which bureaucratic work is demarcated and shielded from external influences. In the current situation, the sovereign act of deciding on asylum cases is performed by a diverse group of actors with often limited and insecure employment contracts. Tasks and responsibilities have become more differentiated. Cases become categorised and streamlined before they even reach case officers' desks, and an even greater focus is put on numbers and outputs. Future research will have to enquire into possible implications of these changes for the realities of work and work cultures within BAMF. It seems fair to expect that any recognition of the individual case and/or the applicant will now require an even greater individual effort on the part of caseworkers. Being a decision-maker in Germany might be "a lonely business", as one interviewee put it, but this loneliness is populated by artefacts, symbols, and emotions indicative of conflictual social relations.

Acknowledgements I would like to thank the editors Nick Gill and Anthony Good for helpful comments and suggestions on an earlier version of this paper. Christian Lahusen also provided valuable feedback for which I am grateful.

\section{References}

Affolter, L. (2017). Asyl-Verwaltung kraft Wissen: Die Herstellung von Entscheidungswissen in einer Schweizer Asylbehörde. In C. Lahusen \& S. Schneider (Eds.), Asyl verwalten: Zur bürokratischen Bearbeitung eines gesellschaftlichen Problems (pp. 145-171). Bielefeld: transcript.

Bohnsack, R. (2010). Rekonstruktive Sozialforschung. 8. Aufl. Stuttgart, [s.l.]: UTB GmbH: Barbara Budrich.

Bourdieu, P. (1989). Social Space and Symbolic Power. Sociological Theory, 7(1), $14-25$.

Bourdieu, P. (1994). Rethinking the State: Genesis and Structure of the Bureaucratic Field. Sociological Theory, 12(1), 1-18. 
Bourdieu, P. (1998). Praktische Vernunft. Zur Theorie des Handels. Frankfurt am Main: Suhrkamp.

Bourdieu, P., \& Wacquant, L. J. D. (2013). Reflexive Anthropologie. Frankfurt am Main: Suhrkamp.

Bowker, G. C., \& Star, S. L. (1999). Sorting Things Out: Classification and Its Consequences. Cambridge, MA and London: The MIT Press.

Bundesamt für Migration und Flüchtlinge. (2016). Das Bundesamt in Zablen 2015: Asyl, Migration und Integration. Nuremberg.

Burkitt, I. (2012). Emotional Reflexivity. Feeling, Emotion and Imagination in Reflexive Dialogues. Sociology, 46, 458-472.

Clarke, A. E. (2003). Situational Analyses: Grounded Theory Mapping After the Postmodern Turn. Symbolic Interaction, 26(4), 553-576.

Clarke, A. E. (2012). Situationsanalyse: Grounded theory nach dem Postmodern Turn (Interdisziplinäre Diskursforschung). Wiesbaden: Springer VS.

Dahlvik, J. (2014a). Administering Asylum Applications. Dissertation, University of Wien.

Dahlvik, J. (2014b). Institutionelle Einsichten: Die Bedeutsamkeit von Schriftlichkeit und Dokumenten im Prozess der Bearbeitung von Asylanträgen. In J. Dahlvik, C. Reinprecht, \& W. Sievers (Eds.), Migration and Integration Research: Jahrbuch 2/2013 (pp. 301-317). Göttingen: V\&R Unipress, Vienna University Press.

Deutscher Bundestag. (2014). Antwort der Bundesregierung auf die Kleine Anfrage der Abgeordneten Ulla Jelpke, Jan Korte, Sevim Dağdelen, weiterer Abgeordneter und der Fraktion DIE LINKE. Ergänzende Informationen zur Asylstatistik für das Jahr 2013. Drucksache 18/705.

Deutscher Bundestag. (2015). Antwort der Bundesregierung auf die Kleine Anfrage der Abgeordneten Ulla Jelpke, Jan Korte, Sevim Dağdelen, weiterer Abgeordneter und der Fraktion DIE LINKE. Ergänzende Informationen zur Asylstatistik für das dritte Quartal 2015. Drucksache 18/6860.

Deutscher Bundestag. (2016). Antwort der Bundesregierung auf die Kleine Anfrage der Abgeordneten Luise Amtsberg, Volker Beck (Köln), Britta Haßelmann, weiterer Abgeordneter und der Fraktion BÜNDNIS 90/DIE GRÜNEN. Personalgewinnung beim Bundesamt für Migration und Flüchtlinge. Drucksache 18/9895.

Englert, K., \& Sondermann, A. (2013). "Ich versuch hier auch immer so dieses Amtliche irgendwie noch 'n bisschen zu überspielen." Emotions- und Gefühlsarbeit in der öffentlichen Verwaltung als Ausdruck von Staatlichkeit im Wandel. Österreichische Zeitschrift für Soziologie, 38(2), 131-147.

Fassin, D., \& Kobelinsky, C. (2012). Comment on juge l'asile. Revue française de sociologie, 53(4), 657.

Gieryn, T. F. (1983). Boundary-Work and the Demarcation of Science from NonScience: Strains and Interests in Professional Ideologies of Scientists. American Sociological Review, 48(6), 781-795. 
Gill, N. (2016). Nothing Personal? Geographies of Governing and Activism in the British Asylum System. Oxford: Wiley-Blackwell.

Good, A. (2015). 'The Benefit of the Doubt' in British Asylum Claims and International Cricket. In D. Berti, A. Good, \& G. Tarabout (Eds.), Of Doubt and Proof: Ritual and Legal Practices of Judgment (pp. 119-140). Farnham: Ashgate.

Hochschild, A. R. (2003). The Managed Heart: Commercialization of Human Feeling (20th anniversary ed.). Berkeley: University of California Press.

Jubany, O. (2011). Constructing Truths in a Culture of Disbelief: Understanding Asylum Screening from Within. International Sociology, 26(1), 74-94.

Klatetzki, T. (2016). Disgust and the Institutions of Cleanliness and Purity in Organizations. In E. Weik \& P. Walgenbach (Eds.), Institutions Inc (pp. 30-62). London: Palgrave Macmillan.

Kreienbrink, A. (2013). 60 Jahre Bundesamt für Migration und Flüchtlinge im Kontext der deutschen Migrationspolitik. Zeitschrift für Ausländerrecht und Ausländerpolitik, 33(11-12), 397-448.

Mannheim, K. (2013 [1936]). Ideology and Utopia: Collected Works of Karl Mannheim (Vol. 1). Hoboken: Routledge.

Moore, S. F. (1972). Law and Social Change: The Semi-autonomous Social Field as an Appropriate Subject of Study. Law and Society Review, 7, 719-746.

Nohl, A. M. (2012). Interview und dokumentarische Methode: Anleitungen für die Forschungspraxis (4th ed.). Wiesbaden: VS Verlag für Sozialwissenschaften.

Probst, J. (2012). Instruire la demande d'asile: Étude comparative du processus décisionnel au sein de l'administration allemande et francaise. Dissertation, Université de Strasbourg and Philipps-University Marburg.

Scheff, T. J. (2000). Shame and the Social Bond: A Sociological Theory. Sociological Theory, 18, 84-99.

Scheffer, T. (1998). Übergänge von Wort und Schrift: zur Genese und Gestaltung von Anhörungsprotokollen im Asylverfahren. Zeitschrift für Rechtssoziologie, 20(2), 230-265.

Scheffer, T. (2001). Asylgewährung. Eine ethnographische Verfahrensanalyse. Stuttgart: Lucius and Lucius.

Schittenhelm, K. (2015). Asylsuchende im Blickfeld der Behörde. Explizites und implizites Wissen in der Herstellung von Asylbescheiden in Deutschland. Soziale Probleme, 26(2), 137-150.

Schittenhelm, K., \& Schneider, S. (2017). Official Standards and Local Knowledge in Asylum Procedures: Decision-Making in Germany's Asylum System. Journal of Ethnic and Migration Studies, 43(10), 1696-1713.

Schmidt, R., \& Volbers, J. (2011). Siting Praxeology. The Methodological Significance of "Public" in Theories of Social Practices. Journal for the Theory of Social Behaviour, 41(4), 419-440.

Schneider, S., \& Wottrich, K. (2017). 'Ohne 'ne ordentliche Anhörung kann ich keine ordentliche Entscheidung machen...' - Zur Organisation von 
Anhörungen in deutschen und schwedischen Asylbehörden. In C. Lahusen \& S. Schneider (Eds.), Asyl verwalten: Zur bürokratischen Bearbeitung eines gesellschaftlichen Problems (pp. 81-115). Bielefeld: transcript.

Staffans, I. (2008). Evidentiary Standards of Inquisitorial Versus Adversarial Asylum Procedures in the Light of Harmonization. European Public Law, 14(4), 615-641.

Star, S. L. (2010). This is Not a Boundary Object: Reflections on the Origin of a Concept. Science, Technology and Human Values, 35(5), 601-617.

Star, S. L., \& Griesemer, J. R. (1989). Institutional Ecology, 'Translations' and Boundary Objects: Amateurs and Professionals in Berkeley's Museum of Vertebrate Zoology, 1907-39. Social Studies of Science, 19, 387-420.

Star, S. L., \& Strauss, A. (1999). Layers of Silence, Arenas of Voice: The Ecology of Visible and Invisible Work. Computer Supported Cooperative Work, 8, 9-30.

Thränhardt, D. (2014). Europäische Abschottung und deutscher Asylstau: Gibt es Wege aus dem Dilemma? Zeitschrift für Ausländerrecht und Ausländerpolitik, 34(5-6), 177-181.

Unabhängige Kommission 'Zuwanderung'. (2001). Zuwanderung gestalten Integration fördern: Bericht der Unabhängigen Kommission 'Zuwanderung'.

Weber, R. (1998). Extremtraumatisierte Flüchtlinge in Deutschland: Asylrecht und Asylverfahren. Frankfurt and New York: Campus-Verlag.

Wettergren, Å., \& Wikström, H. (2014). Who Is a Refugee? Political Subjectivity and the Categorisation of Somali Asylum Seekers in Sweden. Journal of Ethnic and Migration Studies, 40(4), 566-583.

Whyte, Z. (2015). In Doubt: Documents as Fetishes in the Danish Asylum System. In D. Berti, A. Good, \& G. Tarabout (Eds.), Of Doubt and Proof: Ritual and Legal Practices of Judgment. Farnham: Ashgate.

Wikström, H., \& Johansson, T. (2013). Credibility Assessments as 'Normative Leakage': Asylum Applications, Gender and Class. Social Inclusion, 1(2), 92-101. 
Open Access This chapter is distributed under the terms of the Creative Commons Attribution 4.0 International License (http://creativecommons.org/licenses/ by/4.0/), which permits use, duplication, adaptation, distribution and reproduction in any medium or format, as long as you give appropriate credit to the original author(s) and the source, a link is provided to the Creative Commons license and any changes made are indicated.

The images or other third party material in this chapter are included in the work's Creative Commons license, unless indicated otherwise in the credit line; if such material is not included in the work's Creative Commons license and the respective action is not permitted by statutory regulation, users will need to obtain permission from the license holder to duplicate, adapt or reproduce the material. 